\title{
Go Big or Go Home? Lessons Learned from the Colombian Victims' Reparation System
}

\author{
Nelson Camilo Sánchez and Clara Sandoval-Villalba
}

\section{A Introduction}

Colombia has faced an internal armed conflict for over five decades. While a peace agreement was signed in 2016 by the Colombian government and the FARC, the largest guerrilla group (The Colombian Revolutionary Armed Forces), violence persists in many parts of the country. After decades of conflict, there are vast numbers of victims of the atrocious crimes that have been committed. According to the official National Registry of Victims, more than eight million people have been victims of violence, equivalent to $19 \%$ of the overall population in the country. The great majority of these victims are internally displaced persons (IDPs), many of which have suffered more than one serious human rights violation. As of 1 January 2019, there were 218,881 direct victims of homicide and 37,654 direct victims of enforced disappearance since 1985 . $^{1}$

As these numbers indicate, providing reparation in Colombia is no small task. In response to this challenge, Colombia has put in place various tools to respond to the harms caused to victims in a holistic manner, including a very ambitious Domestic Reparation Programme (DRP). ${ }^{2}$ This chapter questions whether these tools have been effective, and reflects on what lessons have been learned.

The assessments of Colombia's ambitious DRP are wide ranging. ${ }^{3}$ Some have positively evaluated aspects of the model, commending its aspiration to follow

Single Registry of Victims, https://cifras.unidadvictimas.gov.co (accessed July 2019).

2 In a recent interview about Colombia, international expert Mark Freeman highlighted ambition as 'one of the things that characterizes Colombia.' In Freeman's words: 'for better and for worse, they [Colombians] can't do anything without being extremely ambitious. I don't mean to say they're not realistic, but they push themselves to the limits.' Mark Freeman, 'How You Can Negotiate Justice and Peace', An interview by Thierry Cruvellier for justiceinfo.net, 30 August 2018, www.https://www.justiceinfo.net (accessed July 2019).

3 There is a wide range of specialised academic literature about the topic. See, for instance, Christine Evans, The right to reparation in international law for victims of armed conflict, (New York: Cambridge University Press 2012); Brett Roddy \& Lina Malagon, 'Overcoming the Original Sin of the "Original Condition": How Reparations May Contribute to Emancipatory 
international legal standards as well as its originality, its goal of expansion, and the creativity with which many debates and challenges have been addressed. ${ }^{4}$ On the other hand, it is common to find critical and pessimistic evaluations that underscore the model's complexity, its lack of practical operability, the gap between law and implementation, and the potential for re-victimisation resulting from the creation of false expectations. ${ }^{5}$

The institutional structure in Colombia today allows for many reflections, and much of the praise and criticism that has been imputed to the DRP is merited. Our general evaluation of the model is mixed: it is neither so disastrous or cynical, nor is it so marvelous. As we cannot discuss each dimension of the reparation puzzle in Colombia in detail here given its complexity, we will concentrate on highlighting some of the DRP's key characteristics. From these reflections, lessons can be drawn which permit transitional justice and human rights practitioners to reflect on the challenges of planning and operationalising robust reparation programmes and systems, like that of Colombia, in contexts of generalised institutional fragility as those found in conflict and post-conflict situations.

The structure of the chapter will be the following: in the first section, we provide a brief overview of the reparation tools available in the country, in which we will include the existing options for accessing reparations, both in transitional and non-transitional mechanisms. This means that in Colombia, there is a plurality of mechanisms to provide reparation to victims of the armed conflict and not exclusively its DRP under Law 1448/2011 (Victims and Land Restitution Law - here in after Law 1448). This is something to be noted as co-existence of systems to provide reparation tends to be overlooked in

Peacebuilding', (2013) 14(3) Hum Rts Rev 257; and Nicole Summers, 'Colombia's Victims' Law: Transitional Justice in a Time of Violent Conflict?' (2012) 25 Harvard Hum Rts J 219. There is also a good number of policy assessment studies. See, Kathryn Sikkink, Phuong Pham, Douglas Johnson, Peter Dixon, Bridget Marchesi \& Patrick Vinck 'Evaluation on Integral Reparations Measures in Colombia', Carr Center for Human Rights Policy and The Harvard Humanitarian Initiative, 2015; Cristián Correa, 'From Principles to Practice: Challenges of Implementing Reparations for Massive Violations in Colombia', International Center for Transitional Justice, 2015; and Nelson Camilo Sánchez \& Adriana Rudling 'Reparations in Colombia: Where to? Mapping the Colombia Landscape of reparations for Victims of the Internal Armed Conflict', The Reparations, Responsibility and Victimhood in Transitional Societies Project, Belfast, 2019.

4 Sikkink et al., ibid; Rodrigo Uprimny, 'Transformative Reparations of Massive Gross Human Rights Violations: Between Corrective and Distributive Justice', (2009) 27(4) Neth Q Hum Rts, 625 .

5 Correa (n 3); Amnesty International, 'Colombia: The Victims and Land Restitution Law: An Amnesty International Analysis', AI Index: AMR 23/018/2012, 17 April 2012. 
specialised literature on the subject and remains a significant aspect of any reparation process. ${ }^{6}$ In the second section, we analyse the progress and challenges in providing reparation to victims under Law 1448, with particular emphasis on some particular forms of reparation like compensation, rehabilitation and land restitution. The third section reflects on the system taking into account the theory on reparation but also similar debates in other countries facing similar challenges. We will also bear in mind the challenges faced by the system in terms of articulation, coordination, and efficiency. Finally, the chapter concludes with some brief conclusions and lessons learned not only about Colombia but the overall challenge of providing reparation to victims in conflict and post-conflict situations.

A Plurality of Mechanisms

Colombia has a relatively complex institutional framework with regards to reparation. First, there is an important set of norms that regulate the conditions under which a person who has suffered harm can access reparation. This framework includes provisions under private and public law regulating damages and torts. Second, specific legal instruments regulate the right to reparation of victims of the Colombian armed conflict. Various institutions including judicial bodies, are responsible for operationalising these laws and granting protection to individuals whose rights have been violated.

\section{$1 \quad$ Reparation through the Ordinary Judicial System}

Under Colombian law, a gross violation of human rights constitutes a crime. Colombian criminal law gives the victims of a crime the right to comprehensive reparation for the harm suffered from the perpetrator or third party determined responsible - this extends beyond compensation. Constitutional jurisprudence has reiterated that victims' right to reparation is not limited exclusively to economic indemnification. ${ }^{7}$

Additionally, the injuries caused can be the object of litigation before civil courts to seek reparation from those who are liable, whether in their personal or corporate capacity. Colombian civil law provides for both direct and indirect (vicarious) extra-contractual civil liability (tort) actions. The former takes place in accordance with article 2341 of the Colombian Civil Code, and

6

7 Constitutional Court, Decisions C-580 of 2002, C-228 of 2003 and C-25o of 2011. 
under such actions, the person who commits an illicit act (through negligence, willful misconduct, or fraud) and causes such damage (any bodily, moral, or material injury) is obliged to indemnify the damage. In the latter case, which is governed by article 2347 of the Colombian Civil Code, a principal is liable to afford reparation for an injury caused by the fault of its employees in the performance of their duties.

Finally, if state officials participated in the events, the system allows victims, once state responsibility is recognised, to request reparations both at the domestic and international level. Since 2002, the Council of State (Consejo de Estado), the highest Court in Colombia for acts or omissions committed by the state or its entities, has incorporated in its jurisprudence the criteria for reparation established by the Inter-American Court on Human Rights (IACtHR) in its well-established jurisprudence on the subject. ${ }^{8}$

Colombia has also ratified the most important international treaties applicable to armed conflicts and their consequences, including the International Covenant on Civil and Political Rights, the American Convention on Human Rights, the Geneva Conventions and their Optional Protocols as well as the Rome Statute. It has equally accepted the jurisdiction of UN treaty monitoring bodies such as the Human Rights Committee and the IACtHR. This means that as a general rule, after individuals in Colombia have exhausted domestic remedies, they can approach any of these bodies claiming that the state has violated their rights and seeking reparations for harms suffered.

\section{$2 \quad$ Transitional Reparation Mechanisms}

In response to the armed conflict, in the early 199os, the Colombian state began to implement measures to help victims access basic services such as health, education, and funeral expenses. These measures, which were initially called "humanitarian aid," included monetary compensation for people who were victimised by what the law deemed to be terrorist acts and, later, by acts derived from the conflict. In this way, the state created the beginning of what would later become the DRP. In the early 2000 s, as a consequence of demobilisation processes of paramilitary groups and victims' mobilisation, the Colombian Congress passed a series of laws that are part and parcel of the current normative transitional justice framework for reparation.

8 Among other examples: Council of State, Third section, 19 October 2007, decision 29273, M.P. Enrique Gil Botero; Council of State, Third section, 20 February 2008, decision 16996, M.P. Enrique Gil Botero; Council of State, Third section, 14 September 2011, decision 19031 and 38222, M.P. Enrique Gil Botero. 
a

Reparations under the Justice and Peace Law

In the context of the demobilisation of the right-wing paramilitary groups that started in late 2002, in July 2005, the Colombian Congress passed Law 975/2005 (known as the Justice and Peace Law) creating a system to handle the most serious violations committed by paramilitary personnel and guerrillas, including disappearances, massacres and sexual violence, through special chambers for criminal trials. The system was similar to the one established in South Africa under the Truth and Reconciliation Commission, where it was imperative that perpetrators confessed all their crimes to be eligible for an amnesty, with the difference that in Colombia, the confession would happen within the framework of criminal proceedings, and there would nonetheless be a punishment albeit attenuated by the confession. ${ }^{9}$ Although, the framework allowed for victim participation, ${ }^{10}$ victims had to wait until confessions were provided and for the stages of criminal responsibility to be over, to later have their reparation requests heard in a special stage called the "reparation incident." There, in addition to listening to the victims, the Tribunal would assess the damages and decide on the reparation measures to be later ordered as part of the sentence."

Law 975 follows international law standards on reparation. As per compensation measures, the system established that the main person responsible for the payment of compensation would be the defendant, but that if the person lacked resources, the armed bloc to which the person belonged or the armed group - as a collective - should take on this responsibility on solidarity grounds. For this purpose, the Law created a reparations fund where all assets given by or taken from the demobilised members of armed groups were to be directed. ${ }^{12}$

In a country with a strong legal culture, it was no surprise that the first attempt to provide reparation to victims was to take place through courts. However, the system soon failed to provide reparation to victims, and to do so in a prompt manner. The processes under the justice and peace law turned out to be - like in any criminal trial -, extremely slow. Furthermore, victims were not always given proper access to the system and there were not enough assets to provide reparation. Indeed, the Ministry of Justice in Colombia calculated that

Indeed, in Colombia, perpetrators would have to confess all their crimes and give up their assets in furtherance of reparation to victims, in order to obtain the special benefits of the law, which were imprisonment between 5 to 8 years.

10 Catalina Díaz, 'Colombia’s Bid for Justice and Peace', International Center for Transitional Justice, 2007.

11 Law 1592, Article 24. Constitutional Court Decision C-180/14.

12 Law 975, Article 54. 
by 2014, there were 5,190 demobilised combatants pending trial and judges had only rendered 26 judgments. This figure gives an indication of the massive challenges ahead if victims were to secure reparation through this Law. ${ }^{13}$ In addition to that, the reparation orders issued by the Justice and Peace Law judges proved to be extremely difficult to implement due to the complex institutional processes that needed to be put in motion to make them happen and the costs they demanded. ${ }^{14}$

In light of the failure of Law 975 to provide prompt reparations to victims, in 2008 the government issued Decree 1290 (regulation of the Justice and Peace Law), which created an 'Administrative Programme for Individual Reparations. ${ }^{\prime 15}$ This decree established that victims of murder, enforced disappearance, kidnapping, torture, sexual violence and forced recruitment, duly registered in the judicial processes of the Justice and Peace Law could obtain partial compensation, in the amounts indicated in the Decree, from the reparation fund, while legal proceedings were still taking place.

b Reparations under the Victims and Land Restitution Law

In light of the profound limitations of both the ordinary system for reparations, and the mechanisms associated with the demobilisation process, victims of the conflict organised themselves and demanded adequate and effective remedies to claim reparation. This gave rise to what would become Law 1448, in 2011. Besides Law 1448, three Decrees with force of law were enacted to regulate the right to reparation of indigenous groups, black communities, afrodescendants and Roma. ${ }^{16}$

Law 1448 incorporated both individual and collective forms as well as material and symbolic forms of redress. Among the individual forms of reparation, it included compensation, rehabilitation for physical and mental health through the Programa de Atención Psicosocial y Salud Integral de Víctimas (PAPSIVI), a land restitution process, satisfaction measures, and other forms of restitution such as housing, education and employment measures, particularly for displaced persons. The law includes victims of armed groups, regardless of whether

13 Ministry of Justice, 'Justicia transicional en Colombia' http://www.justiciatransicional.gov. co/Justicia-Transicional/Justicia-transicional-en-Colombia, (accessed 8 April 2019).

14 For example, Corte Suprema de Justica, Segunda instancia, Sala de Casación Penal, Jorge Ivan Laverde Zapata, Magistrate Luis Guillermo Salazar Otero, 6 June 2012.

15 República de Colombia, Decree no 1290, 22 April 2008, https://www.refworld.org/ cgi-bin/texis/vtx/rwmain/opendocpdf.pdf?reldoc=y\&docid=542d161d4, $\quad($ accessed 8 April 2019).

16 Respectively Decrees 4622/2001, 4635/2011 and 4634/2011. 
they have demobilised, and also of state agents, something that had not been covered under the Justice and Peace Law.

An important principle giving internal coherence to the forms of reparation under Law 1448 was the decision to provide victims with a holistic and integral approach to reparation. This principle applies not only through the understanding of the way different forms of reparation should be amplified, for example, by providing victims with financial education for the investment of compensation, but also through team work where dialogue and reflection about harm, truth, and moving forward are encouraged. The Law also includes the imprint of transformative reparations. ${ }^{17}$

The law establishes a new institutional framework called the SNARIV (Sistema Nacional de Atención y Reparación a las Víctimas), exclusively for the reparation of victims under this Law. It establishes new structures including the Victims Unit, the Land Restitution Unit, the National Center for Historic Memory (NCHM) ${ }_{1}^{18}$ and the National Registry of Victims.

The Law also provides for an administrative programme for individual reparations that updated, and ultimately replaced, the one created by Decree 129 . In addition to compensation or restitution, the new programme also provides for state support to guarantee rights related to education, health, housing, employment and income generation programmes, among others. The Law equally include interventions designed to return victims their dignity, to preserve memory, recover the truth, and create the necessary conditions so that the events they experienced are not repeated.

Article 3 of Law 1448 of 2011 also establishes that victims can access satisfaction measures through Regional Victims' Unit Centres or through the Centre for Historical Memory (CHM) and judicial rulings. These measures aim to recognise the right of victims, their family members, and society in general to know the truth about the events, motives and circumstances of what happened. Thus, this component must cover two dimensions: the historical truth and memory reconstructed by state institutions as well as civil society; and the judicial truth, established through judicial proceedings against the perpetrators of atrocious crimes. The latter is developed through the justice system, but it is understood as a complement to the historic truth.

17 Law 1448, Article 25.

18 The chapter on satisfaction measures in Law 1448 of 2011 included the creation of the Center for Historical Memory (смн), which referred to the work done by the Historical Memory Group (GMH) under the National Commission for Reparation and Reconciliation (CNRR) created by the Justice and Peace Law, and whose working cycle ended in December 2011. 
It is worth nothing that Law 1448 also created a programme of collective reparation aimed at benefitting social and political groups and organizations, as well as communities. These groups are defined in a flexible manner to include any collective that is linked together through cultural ties, the zone or the territory they inhabit, or a common purpose. ${ }^{19}$

The peace agreement between the Government and the FARC contains a special chapter on the rights of victims where the right to reparation is also recognised. The agreement created a new full set of mechanisms to deal with truth, justice, and the search for the disappeared. However, it did not create a new mechanism or rules to deal with reparation. Instead, the agreement fully validates the reparations system under Law 448 and adds some important nuances such as that the FARC would contribute conflict assets to the reparation process and that both the Government and the FARC would carry out memory and satisfaction measures for the victims. ${ }^{20}$ The agreement also includes territorial programmes with a development focus to help the most marginalised communities in the country. ${ }^{21}$

\section{Victims' Road to Access Reparation}

As a general rule, to access individual reparations, victims have to register in the Single Registry of Victims (Registro Unico de Víctimas - RUV). This can be done before any entity of the Ministerio Público (Public Ministry) and Ombudsman Offices in Colombia or before any consulate of Colombia abroad. Victims should provide a declaration, which is subsequently revised by the Victims Unit that decides whether the person can be recognised as a victim. Part of the corroboration process is done by the Victims Unit by comparing the information received with that contained in the National Information Network to Assist and Repair Victims (Red Nacional de Información para la Atención y Reparación de Víctimas). The registration process is carried out on the basis of good faith. The Unit has 6o days to decide on the registration process. Victims can also be registered as a result of a judicial decision, for example, of a judgment of the Justice and Peace Law or as part of land restitution process. If the person is registered as a victim, the Unit is responsible for supporting victims through the various processes established by the Law and other regulations to obtain individual reparation. The Unit is responsible for paying compensation,

\footnotetext{
19 Law 1448/2011, Articles 151-152.

20 Peace Agreement, points 5.1.3 and 5.1.4.

21 Peace Agreement. See, Agreement on Comprehensive Rural Reform.
} 
but all other forms of reparation are provided by other institutions that form the SNARIV.

The effective implementation of individual and collective forms of reparation depends on various factors but one that is central is the accurate calculation of the universe of victims to be redressed and the overall costs of the implementation of the DRP. This is by no means an easy task.

In Colombia, when Law 1448 was approved by Congress, it was based on the expectation that there were approximately 4.5 million victims and that the total costs of implementing such an ambitious Law would be 54.9 billion Colombian pesos. ${ }^{22}$ However, as of today, the Registry of Victims indicates that there are approximately 8.7 million victims, and registration continues. As of 2018, the Colombian Government had set aside 76.9 billion pesos for the work of the DRP. ${ }^{23}$

While there is a clear disconnect between the original projections and the actual number of victims that have registered, a key challenge for the system arose when the Constitutional Court changed the reparations that could be given to IDP s. ${ }^{24}$ Basically, the Constitutional Court in upholding the right to reparation of IDP victims, considered that they were also entitled to compensation. This judgment has had a negative impact on the implementation of the Law as the number of victims eligible for compensation grew exponentially. Equally, there is a general disconnect between the original projections and what the Law would require for reparation to be fully implemented.

While all forms of reparation are important to provide victims with adequate reparation, the next sub-sections look at three forms of reparation included in Colombia's DRP: compensation, rehabilitation and land restitution. This allows one to contrast simple forms of reparation and their implementation as in the case of compensation, with more complex measures such as rehabilitation and land restitution.

\section{$1 \quad$ Compensation}

Compensation is meant to be paid to indirect victims of enforced disappearances or killings only and to direct victims of kidnapping, torture and other

22 Departamento Nacional de Planeación, Consejo Nacional de Politica Economica y Social, Documento CONPES 3712, Plan de Financiación para la Sostenibilidad de la Ley 1448 de 2011, 1 December 2011.

23 Comisión de Seguimiento y Monitoreo a la Implementación de la Ley 1448 de 2011 "Ley de Víctimas y restitución de Tierras", Quinto informe de Seguimiento al Congreso de la República, 17 August 2018, 29. 
cruel, inhuman or degrading treatment, sexual violence, child recruitment and displacement. However, in relation to displacement as well as to indirect victims of enforced disappearances and killings, the payment is made to the family unit and not to individual members of the family, ${ }^{25}$ as shown in Table below:

TABLE 21.1

\begin{tabular}{|c|c|c|}
\hline \multirow[t]{6}{*}{ Direct Victims } & Kidnapping & $\begin{array}{l}\text { 10,500 USD per individual } \\
\text { (40 minimum monthly wages) }\end{array}$ \\
\hline & $\begin{array}{l}\text { Injuries that result in permanent } \\
\text { disability }\end{array}$ & $\begin{array}{l}\text { 10,500 USD per individual } \\
\text { (40 minimum monthly wages) }\end{array}$ \\
\hline & Torture and CIDT & $\begin{array}{l}\text { 7,900 USD per individual } \\
\text { (30 minimum monthly wages) }\end{array}$ \\
\hline & Sexual violence & $\begin{array}{l}\text { 7,900 USD per individual } \\
\text { (30 minimum monthly wages) }\end{array}$ \\
\hline & $\begin{array}{l}\text { Forced recruitment of children } \\
\text { who were released by the age of } 18\end{array}$ & $\begin{array}{l}\text { 7,999 USD per individual } \\
\text { (30 minimum monthly wages) }\end{array}$ \\
\hline & Forced displacement & $\begin{array}{l}\text { 4,500 USD ( } 17 \text { minimum monthly } \\
\text { wages per household) }\end{array}$ \\
\hline Indirect Victims & Forced disappearances & $\begin{array}{l}\text { 10,500 USD ( } 40 \text { minimum monthly } \\
\text { wages per family to be divided } \\
\text { between the family unit) }\end{array}$ \\
\hline & Killings & $\begin{array}{l}\text { 10,500 USD ( } 40 \text { minimum monthly } \\
\text { wages per family to be divided } \\
\text { between the family unit) }\end{array}$ \\
\hline
\end{tabular}

Up until 31 December 2017, a total of 759,341 victims had received compensation under the DRP for a total of 4,824,578 billion pesos. ${ }^{26}$ Current numbers indicate that about $10 \%$ of the approximately 7 million victims that should receive compensation, have been receiving it on a yearly basis, and indeed,

25 Other DRP s have provided reparation to next of kin on different bases. See Ruth RubioMarín, Clara Sandoval and Catalina Díaz, 'Repairing Family Members: Gross Human Rights Violations and Communities of Harm', in Ruth Rubio-Marín, The Gender of Reparations (NY: CUP 2009), 215-29o.

26 Comisión de Seguimiento y Monitoreo a la Implementación de la Ley 1448 de 2011 "Ley de Víctimas y restitución de Tierras", Quinto informe de Seguimiento al Congreso de la República, 17 August 2018, 193. 
projections indicate that at this pace it will take 57 years to compensate this universe of victims. ${ }^{27}$

While almost 800,000 compensation payments in eight years of implementation of the Law is a significant figure that should not to be underestimated, the result is far from satisfactory. Certainly, it is very costly to provide compensation to approx. 7 million victims (if we take into account those already paid and those who have died). Nevertheless, making such a payment should be facilitated by the fact that it is a one-time payment, and not a pension for life as was the case for certain gross human rights violations of the dictatorship in Chile. Furthermore, in Colombia, the majority of victims that are registered are, in principle, reachable. Security conditions may hinder the payment of compensation but that is not an issue that is faced by the system but rather by the victims who benefit from it.

If one compares the result of Colombia so far with actual compensation paid in Guatemala, for example, Colombia comes out well on the assessment. In Guatemala, of approximately 200,000 victims entitled to reparation, approximately 32,000 have received compensation. ${ }^{28}$ This was the number after 11 years of implementation of the National Reparation Programme. But in Guatemala, the financial and political conditions are rather different than in Colombia.

One could also compare the Colombian approach to the results of the German Compensation Programme for Forced Labour. Then, the assessment of Colombia is less positive. Indeed, in the case of the German Compensation Programme, it provided compensation in two instalments to 1.6 million victims of forced labour across 89 states, between 2000 and 2007. The total cost of compensation was 5.2 billion euros, paid in equal shares by the German Government and German corporations. ${ }^{29}$

\section{2}

\section{Rehabilitation}

Rehabilitation for physical and mental health ${ }^{30}$ falls within the remit of the Ministry of Health through the papsivi. Nevertheless, the Victims Unit has also

27 Ibid, 19.

28 Programa Nacional de Resarcimiento, Cantidad de beneficiarios por tipo de violación del 2005-2014 (Guatemala, PNR).

29 Friederike Mieth and Günter Saathoff, 'Introduction' in Günter Saathoff, Uta Gerlant, Friederike Mieth and Norbert Wühler (eds), The German Compensation Program for Forced Labor: Practice and Experiences, (Berlin: Foundation Remembrance Responsibility Future (EVZ), 2017) 1-12, 2. 
developed a psychosocial support programme for victims named the Strategy for Emotional Wellbeing (Estrategia de Recuperación Emocional -ERE), partly due to the deficit in provision of this service by the Ministry of Health. While rehabilitation services were foreseen in Law 1448 , they only began to be provided in 2014. Since then and up to 2018, 418,411 survivors have been provided with rehabilitation measures, ${ }^{31}$ when the expected universe of victims requiring such services is approximately $3,472,453$ victims. ${ }^{32}$ This means that $12.41 \%$ of the victims have received some form of rehabilitation.

It must be noted that the PAPSIVI is available in various Departments in Colombia but does not fully reach all areas of the country. Even in areas where violence has been rampant, as in Antioquia and Valle del Cauca, not all their municipalities are covered by the PAPSIVI. ${ }^{33}$ Furthermore, Departments have an obligation to make financial allocations to fund PAPSIVI services but 12 out of 29 departments in the country have yet to make such contributions. ${ }^{34}$ The lack of adequate implementation of rehabilitation services in Colombia has even led the IACtHR to monitor compliance with its orders on rehabilitation in various judgments by joining them in nine cases related to victims of human rights violations that occurred during the armed conflict. ${ }^{35}$

While the implementation and provision of rehabilitation services through the PAPSIVI faces enormous challenges, an important form of rehabilitation, that is collective in nature, was designed by the Victims Unit as a tool to respond to the massive psychosocial harm caused in many communities. This programme has been called 'Entrelazando' which means 'interweaving'. The

31 Comisión de Seguimiento y Monitoreo a la Implementación de la Ley 1448 de 2011 "Ley de Víctimas y restitución de Tierras", Quinto informe de Seguimiento al Congreso de la República, 17 August 2018, 113 .

32 Ibid, 119.

33 Ibid, 115 .

34 This includes violent areas of the country where many victims are located like Meta, Choco, or Valle del Cauca. See, ibid, 117.

35 The nine cases are: Case of the 19 Tradesmen v. Colombia (Merits, Reparations and Costs) Ser C No 109, 5 July 2004; Case of Gutiérrez Soler v. Colombia (Merits, Reparations and Costs) Ser C No 132, 12 September 2005; Case of the "Mapiripán Massacre" v. Colombia (Merits, Reparations and Costs) Ser C No 134, 15 September 2005; Case of the Pueblo Bello Massacre v. Colombia (Merits, Reparations and Costs) Ser C No 140, 31 January 2006; Case of the Ituango Massacres v. Colombia (Preliminary objections, Merits, Reparations and Costs) Ser C No 148, 1 July 2006; Case of the La Rochela Massacre v. Colombia (Merits, Reparations and Costs) Ser C No 163, 11 May 2007, Case of Escué Zapata v. Colombia (Merits, Reparations and Costs) Ser C No 165, 4 July 2007; Case of Valle Jaramillo et al. v. Colombia (Merits, Reparations and Costs) Ser C No 192, 27 November 2008 and the Case of Manuel Cepeda Vargas v. Colombia (Preliminary Exceptions, Merits and Reparations) Ser C No 213, 26 May 2010. 
object of the programme is to ensure that the social fabric can be reconstructed through the work carried out by different 'interweavers'. Lina Rondon, who began and coordinated the programme at the Victims Unit indicates that 'the process began as a strategy to understand and respond to the collective psychosocial harms that were most evident in peasant communities between October 2012 and May 2016.36

The programme has three key points of contact: two leaders in the community, fictionally called Julia and Cristobal, who during the conflict, resisted the violence and kept on going; some professional interweavers that work locally with the community and the Victims Unit that articulates the process. Communication between these three elements of the network has helped to improve understanding of the different facets of harm and have also helped to facilitate four different processes aimed at rebuilding the community: collective mourning, transforming the meaning of places plagued by horror and violence, rescuing social practices important for the community, living with each other and nurturing collective imaginaries. ${ }^{37}$

Two features of the programme stand out: first, that it has proven to be an effective form of rehabilitation for the communities where it has been implemented despite being a simple and affordable form of intervention and second, that it builds the social fabric placing the community and its members at the heart of the process. The fact that a social leader is the interweaver means that when the Victims Unit leaves the community, the process of healing and social cohesion can continue.

Rehabilitation is a crucial form of reparation for victims. Without it, many victims will not be able to exercise their right to justice or truth or become a meaningful agent in society. ${ }^{38}$ However, in Colombia as in many states ravaged by conflict, the provision of rehabilitation services faces many challenges, ${ }^{39}$ making it difficult if not impossible to provide the services as required.

36 Lina Rondón, 'Reconstruir el Tejido Social. Un Trabajo por Hacer con las Comunidades Afectadas y una Orientación Dirigida a Rehumanizar la Sociedad', in Keilyn Julieth Sanches Espitia (ed) Entre Acuerdos y Desacuerdos: Memorias de una Paz en Disputa, (Bogota, UD Editorial 2018), 152.

37 Ibid, $153^{-154}$.

38 Clara Sandoval, 'Rehabilitation as a Form of Reparation Under International Law', redress, 2009 and Clara Sandoval, 'Reflections on the Transformative Potential of Transitional Justice and the Nature of Social Change in Times of Transition, in Roger Duthie and Paul Seils (eds), Justice Mosaics: How Context Shapes Transitional Justice in Fractured Societies, (NY: ICTJ 2017), 166-201, 190.

39 Judith Bueno de Mesquita, Gen Sander and Paul Hunt, 'Rehabilitation and the Right to Health in Times of Transition' in (2016) 5(2) Intl Hum Rts L Rev (2016), 169-193. 
Challenges include the high number of victims - the great majority of which are IDP s; lack of quality coverage of the health system across the country and poor security conditions. However, programmes like Entrelazando show the potential for creative interventions that can help to empower victims and that may be helpful when there are financial constraints.

Probably the most successful comparative experience to date in providing health measures as rehabilitation, has been the still running Chilean PRAIS System (Programa de Reparacióny Atención Integral de Salud), set up in $1991^{40}$ as a result of a recommendation made by the Chilean Truth and Reconciliation Commission. ${ }^{41}$ The programme has provided services to three generations of beneficiaries - both direct and indirect victims - equivalent to approximately 800,00o registered victims. This programme not only engages with health services for the victims but also with memory and truth interventions, accompanying for example, the next of kin of persons who were disappeared during exhumations. Yet, even programmes of this breadth have faced challenges to provide reparation to some victims such as refugees or persons in exile. ${ }^{42}$ It must be noted that Chile was not transitioning from conflict to peace but from dictatorship to democracy.

\section{$3 \quad$ Land Restitution Programme}

Law 1448 established a mixed transitional mechanism to deal with the specific problem of land dispossession. The law created a Land Management Unit as well as special judges and chambers for land restitution. The Land Management Unit receives victims' requests, supplements them with proactive investigation of the specific facts and general patterns of violence, and presents petitions on their behalf to the judges, in areas that have previously been declared by the Government to be zones affected by generalised violence. The land restitution decisions are rendered in an absolute four-month term, ${ }^{43}$ after a 3o-day probation period, and cannot be appealed. The Law also considers monetary compensation payments for third parties who possess the land in

40 Elizabeth Lira, 'Reflections on Rehabilitation as a Form of Reparation in Chile after Pinochet's Dictatorship', (2016) 5(2) Intl Hum Rts L Rev 194.

41 Chilean National Truth and Reconciliation Commission, Report, Volume I, Part II, 1991, 1260-1263.

42 Garcia Lucero and Others v. Chile (Preliminary Objections, Merits, Reparations and Costs) Ser C no 627, 28 August 2013 .

43 As of July 2016, according to data by the Unidad de Restitución, the average duration of this process in the judicial phase was 14 months. For an analysis of the duration of the processes in the administrative phase, please see: Corte Constitutional, Sentence T-415 of 2013 . 
good faith and for those victims to whom it would be impossible to restore their original assets. This compensation is paid, in whichever case, with domestic public bonds, issued by the Government and managed by the National Bank, at the market value of the property at the moment of the ruling.

As of February 2019, the Land Management Unit reported that in the administrative stage of land restitution there were a total of 120,876 requests recorded by the Dispossessed and Forcibly Abandoned Land Registry. These applications have been submitted by 84,005 individuals accounting for 110,007 properties. 54,19o requests have already been processed: 44,602 were discarded and the remaining 9,588 were adjudicated in 4,912 judicial sentences that have benefitted 45 ,ooo people and covered 338,362 hectares of land. A further 17,814 requests are still pending decision by the courts but have already been processed by the Unit. ${ }^{44}$

Regarding restitution processes for ethnic peoples' territories, the Unit reports that as of February 2019, there were 126 cases requested or initiated ex officio: $6 \mathrm{o}$ in undergoing preliminary assessment, $5^{2}$ lawsuits filed before the land restitution jurisdiction, and 101 precautionary measures ordered by judges. $^{45}$

The assessment of the reparations policy in a political transitional context like the Colombian one faces important methodological challenges and ideological and political disputes. An example of this is the disparity in the conclusions of the main land restitution evaluation reports. While some sectors report considerable success in the measures ${ }^{46}$, others show their dissatisfaction regarding what they view as a poor or mediocre result in the implementation. ${ }^{47}$ The disparities have diverse origins. In some cases, differences are due to the scale of the measurements used (victimisation estimates, progress indicators - such as how much money has been invested, how many measures have been granted-, or the baseline). In other cases, it is due to the studies on

44 Land Restitution Unit, Land Restitution Statistics, 14 February 2019, <https://www.restituciondetierras.gov.co/estadisticas-de-restitucion-de-tierras> (accessed 8 April 2019).

45 Land Restitution Unit, Land Restitution Statistics, ibid.

46 According to the current Director of the Land Management Unit, the work of the system has exceeded expectations in terms of numbers of cases managed in the administrative stage. The original estimate was of 9,500 processed cases per year. Between 2012-2018, the system processed 69,419 requests, which on average represents almost 10,00o requests a year. Andrés Castro, 'Política de restitución de tierras no ha cambiado, El Espectador, 25 March 2019, <https://colombia202o.elespectador.com/pais/politica-derestitucion-de-tierras-no-ha-cambiado-andres-castro> (accessed 26 March 2019).

47 Jemima García-Godos and Henrik Wiig 'Ideals and Realities of Restitution: the Colombian Land Restitution Programme', (2018) 10(1) J Hum Rts Practice 40. 
victims' perceptions, where a majority respond negatively to the question of whether they are satisfied with the reparation received. ${ }^{48}$

\section{An Assessment of Reparations for Victims of Mass Atrocities in Colombia}

Reparation for victims of mass atrocities remains an unfinished business. Victims around the world continue to wait for reparation and the great majority of them die with an unfulfilled right and expectation. ${ }^{49} \mathrm{DRP}$ s have been set up to respond to this reality. They are considered to be more conducive to reparation for thousands if not millions of victims. They are meant to be victim-centred remedies that prevent victims from incurring unaffordable costs, or having to satisfy very high standards of proof that they suffered material and moral damages as a result of human rights or humanitarian law violations. ${ }^{50}$

However, after almost three decades of experiences around the world with such programmes as part of transitional justice efforts, the great majority of domestic reparation programmes continue to face enormous challenges to ensure that victims receive adequate, prompt and effective reparation. The great majority of them have simply failed the task. ${ }^{51}$ Very few could be considered to have fulfilled the right to reparation of their beneficiaries.

Important distinctions need to be drawn between reparation for victims of state-sponsored repression as in Chile or Argentina, which could be regarded as more successful programmes, and those domestic reparation programmes set up in countries moving away from conflict such as Colombia. ${ }^{52}$ In Chile and Argentina, the amount of victims was far smaller than in the latter Colombian case, state institutions were in place and were strong and the political transition allowed reparation for victims of mass atrocities to gain traction. In conflict situations state institutions do not exist or are fragile; oftentimes they also lack technical expertise and cross-country reach. There are also other

48 For a comprehensive study on land restitution, see: Nelson Camilo Sánchez, 'Tierra en Transición: Justicia Transicional, restitución de tierras y política agraria en Colombia', Colección Dejusticia, 2017.

49 UN Special Rapporteur for the Promotion of Truth, Justice, Reparation and Guarantees of non-Recurrence, Report to the UN General Assembly, UN Doc A/69/518, 14 October 2014 , para. 6 .

$50 \quad$ Ibid, para. 4.

51 Pablo de Greiff (ed), The Handbook of Reparations (Oxford: Oxford University Press 2005).

52 Roger Duthie and Paul Seils (eds), Justice Mosaics: How Context Shapes Transitional Justice in Fractured Societies (NY: ICTJ 2017), 13. 
actors, particularly armed groups, that make the delivery of reparations even more challenging. ${ }^{53}$

Chile has provided reparation to victims of the dictatorship with a greater degree of success to that of states transitioning from armed conflict. Even today, after almost thirty years since the domestic reparation programme began to work in Chile, it continues to provide some forms of reparation to victims. ${ }^{54}$ Certainly, it has not been a perfect programme. Some victims have been excluded as is the case of refugees or those in exile but overall, the programme has reached out to victims, delivered the benefits and, over the years, has taken action to correct its shortcomings.

Other reparation programmes such as the German Compensation Programme for Forced Labour indicate that reparation could be effectively delivered to victims. ${ }^{55}$ This programme was successful because there was a good calculation of victims, it focused only on compensation and the financial resources to pay for it were in place. It also benefited from strong institutional/ operative frameworks to reach out to victims.

In other contexts, some of them conflict states, lack of reparation has been a feature of their transitional justice processes. South Africa, for example, has failed to fully deliver on reparation for victims even though the TRC made very important recommendations on the subject, and the ANC got to power. ${ }^{56}$ Lack of reparation in South Africa prompted, among others, the Khulumani litigation which brought other actors into the equation, like US courts, but arguably with no positive outcome. ${ }^{57}$ In Sierra Leone, victims are still waiting for reparation despite the recommendations made by the truth commission. The few reparations that have taken place in Sierra Leone were primarily funded by the international community. 58

Where is Colombia on this landscape and what are the lessons to be learnt from the Colombian experience? Law 1448 has been implemented since 2011.

53 Lars Waldorf, 'Institutional Gardening in Unsettled Times: Transitional Justice and Institutional Contexts' in Duthie and Seils, ibid, 40-83.

54 Elizabeth Lira, 'The Reparations Policy for Human Rights Violations in Chile', in de Greiff (ed), The Handbook of Reparations ( $\mathrm{n}_{51}$ ).

55 Clara Sandoval and Miriam Puttick, 'Reparations for the Victims of Conflict in Iraq: Lessons Learned from Comparative Practice', Minority Rights Group, 2017, 4.

56 Chris Colvin, 'Overview of the Reparations Program in South Africa' in de Greiff, The Handbook of Reparations, (n 51) 176.

57 Mia Swart, 'Requiem for a Dream?: The Impact of Kiobel on Apartheid Reparations in South Africa', (2015) 13(2) JIntl Crim J 353.

58 ICTJ, 'Report ad Proposals for the Implementation of Reparations in Sierra Leone', $2009,14$. 
This process has taken place in a rocky context that includes factors such as the failure of the Justice and Peace Law system to provide reparation to victims as decided by judges, several policies on IDP s implemented in Colombia, separate judgments from the IACtHR ordering diverse forms of reparation to victims of mass atrocities, the heavy involvement of the Colombian judiciary, and the negotiation and subsequent signature of the peace agreement between the Government and the FARC.

While transitional justice mechanisms have been established in Colombia, including to provide reparation, the conflict has not fully ended. The presence of diverse layers of violence continue to ravage parts of the country. Ideological polarisation persists, and society in general has not fully come to terms with the idea that Colombia needs to move away from conflict and has to deal with the legacy of its past, including repairing the unspeakable harms suffered by more than 8 million victims, 7 million of which are IDP s.

But Colombia, in contrast to other conflict-affected states, such as Sierra Leone, Liberia or the Central African Republic, has had a stable economy during this century with inflation below $4 \%$ and with economic growth. Nevertheless, it remains a country with one of the highest concentrations of income inequality ${ }^{59}$ and unequal land distribution in the continent. ${ }^{60}$

While economically speaking it would be very demanding for Colombia to pay the costs of its reparation efforts under Law 1448, it is not it's financial inability what makes it the biggest challenge but rather the combination of other features such as the political deficit to support the programme, the lack of contributions from others than the state to finance reparation (for example, armed groups or economic actors), the persistence of conflict in various quarters of the state, and the lack of institutional and technical capacity across the state apparatus, with notorious absence in the areas that have been ravaged by conflict. ${ }^{61}$

The results after eight years of implementation illustrate this reality. While the number of potential victims taken into account when drafting Law 1448 basically doubled (moving approx. from 4 to 8 million), the reality is that not

59 Dane, 'Boletin Tecnico, Pobreza Monetaria y Multidimensional en Colombia', 2017, 13, <https://www.dane.gov.co/files/investigaciones/condiciones_vida/pobreza/bol_ pobreza_1 7.pdf> (accessed 8 April 2019).

6o Ana María Ibánez and Juan Carlos Muñoz, 'The Persistence of Land Concentration in Colombia: What Happened Between 2000 and 2009?', in Morten Bergsmo, César Rodríguez-Garavito, Pablo Kalmanovitz and Maria Paula Saffon (eds), Distributive Justice in Transitions (Oslo: Torkel Opsahl Academic EPublisher 2010), 279.

61 Alexander de Segovia, 'Financing Reparations Programs: Reflections from International Experience,' in de Greiff, The Handbook of Reparations, (n 51 ) $65^{2}$. 
even $50 \%$ of the initial number in mind have received reparation in any of its forms up to 2019. Therefore, by 2021 when the Law would have been in place for a decade, Colombia would have not been able to provide reparation to victims according to its initial plans and more than $85 \%$ of its victims would still be waiting for reparation.

Colombia also designed a reparation programme that is off international charts. No other domestic reparation programme in the world is as ambitious and comprehensive. In a way, the Colombian effort was to respond, as far as possible, to a holistic view of what reparation for victims of armed conflict should be rather than to what was possible in an imperfect world. ${ }^{62}$

Its design was also strongly influenced by the jurisprudence on reparation of the IACtHR, and by its own local courts, which together have developed a very holistic view of reparation for mass atrocities. Nevertheless, when one looks at other conflict situations in the Americas and how DRP s have been designed, no other programme replicates the Colombian approach. Guatemala or Peru, where the number of victims was not even $5 \%$ of the overall number of victims in Colombia (if IDP s are included), have designed complex programmes that combine individual and collective forms of reparation and go beyond compensation, but they do not include the same holistic approach and humanitarian measures as Law 1448. The most recent reparation programme to be set up in the region, that of El Salvador, is also modest in comparison. It covers a few human rights violations, specifically, torture (including sexual violence), killings and enforced disappearances. It provides various forms of reparation to victims. However, some of them, such as rehabilitation, are conditioned to available resources. ${ }^{63}$

Participation by victims during the approval of Law 1448 also influenced its content. At the time, the United Nations Development Programme promoted various regional dialogues between authorities and victims to discuss the content of the draft law. This also helped the Law become holistic. A consequence is that victims' expectations have risen exponentially: they understand reparation in a very holistic manner and are ready to challenge the conduct of the state for failure to implement the Law in their favour.

All of these important developments have also empowered victims who are mobilising, with the help of civil society organisations, to claim their right to reparation. However, some of this mobilisation has occurred because of the great frustration they experience given the lack of implementation of Law

62 Pablo de Greiff, 'Theorizing Transitional Justice', (2012) 51 Nomos 31.

63 Presidency of El Salvador, Decree 204/2013, Articles 2, 7 and 10. 
1448. Consequently, they are approaching national and international bodies to seek adjudication on reparation. This adds yet another layer of complexity to reparation in Colombia. ${ }^{64}$ These additional bodies are deciding on reparation, not always in harmony with the standards applied under Law 1448, which arguably generates a further disservice to victims.

What would have been the alternative to the panorama present today in Colombia? Some scholars like Correa indicate that 'a modest approach that acknowledges the state's limited ability to provide reparations for the dimensions of violations that were suffered by so many may be preferable, instead of overselling an effort that continues to leave many victims waiting.' 65 And he adds "There is little merit in creating a comprehensive and broad reparations program if it is impossible to implement. ${ }^{\prime 6}$ Based on this view, it would have been preferable to design a reparation programme that did not overpromise what it could achieve as this would have led to more targeted outcomes.

The Law is two years away from its expiry date in 2021, and reparation for victims remains an unfinished business. As we have learned from other experiences worldwide, reparation for such atrocities cannot be fulfilled within a decade, even if some of the measures could. Also, most of the work on reparation under a DRP happens during its first five years of work as it is then when state political and financial support are more apparent as well as support from the international community. Equally, DRP s, with holistic principles underpinning their work, last for at least a generation as the Chilean case shows. Therefore, the extension of the Law is necessary. The year 2021 offers an important opportunity for policy makers, victims and civil society to come together to propose amendments to the law bearing in mind the lessons learned.

The potential reform of Law 1448 should take into account how difficult it is to predict the trajectory of a public policy of this nature. Also reform must bear in mind that there is a long-standing institutional experience that carries a baggage of both positive and negative aspects. Two complex lessons that have been learnt require some elaboration: the importance of judicial engagement with reparation measures and the experience of dealing with IDP s.

In all types of states, including consolidated democracies, tensions exist between the branches of public power. However, in a state with chronic institutional weaknesses, these tensions are more frequent and run deeper. This is the

64 Clara Sandoval, 'Two steps forward, one step back: reflections on the jurisprudential turn of the Inter-American Court of Human Rights on domestic reparation programmes' (2018) 22(9) Intl J Hum Rts 1192.

65 Correa, 'From Principles to Practice' (n 3), 28.

66 Ibid. 
case in Colombia, but with two additional contextual factors. The first is an entrenched legal culture which, in the absence of a political consensus, causes powerful actors to convert their disputes into legal battles. The second tension occurs between traditional or ordinary institutions and transitional mechanisms.

Due to these factors, the Colombian judiciary has been a fundamental actor in the Colombian transition, including on the topic of reparations. A potential reform should take into account at least three positive aspects of this judicial intervention. First, Colombia's judiciary has embedded the right to reparations in domestic law by recognising specific international standards, mostly those coming from the jurisprudence of the IACtHR. Second, courts have played a fundamental role in encouraging the participation of victims in the design, planning and monitoring of reparation policies. And third, the courts have confronted the culture of state non-compliance of the law by creating innovative monitoring processes of their decisions. ${ }^{67}$

However, judicial intervention in a process of mass reparation has also significant challenges. Different judges could adjudicate on individual harm and come up with different reparation standards per case, which would delay reparation massively, and generate tensions and harm between victims as has happened in the case of the Justice and Peace Law. Judges could also take decisions that change and expand the reparation policy as happened in Colombia with the decision of the Constitutional Court to uphold the right to compensation of IDP s. ${ }^{68}$ Finally, there are also questions as to the knowledge and capacity of judges to both order complex forms of reparation, such as rehabilitation or property restitution, and monitor the work of a complex web of actors and policies in the country.

This puts on the table an important question related to the kind of coexistence between the judiciary, nationally and internationally, and DRPS. Colombia has an opportunity in 2021 to consider how best to harmonise this relationship.

Additional institutional experience, that should inform the reform process, relates to the efforts to provide reparations to IDPs. According to UNHCR,

67 Two interesting examples are the Constitutional Court's monitoring process of its decisions regarding forced displacement. See Cesar Augusto Rodríguez \& Diana Rodríguez Franco, Radical Deprivation on Trial: The Impact of Judicial Activism n Socioeconomic Rights in the Global South, (Cambridge University Press 2015), and the monitoring processes of the land restitution sentences and decisions. See, Aura Bolívar, Laura Gabriela Gutiérrez, Nelson Camilo Sánchez and Rodrigo Uprimny, 'Debates sobre la Acción de Restitución', Colección Dejusticia, 2017. 
Colombia has the second highest number of displaced persons worldwide after Syria. Of the 7.9 million displaced persons in Colombia, 7.7 are internally displaced persons, which is 1.5 million more than the group of internally displaced persons in Syria. ${ }^{69}$ This means that out of the 40 million internally displaced persons in the world, Colombia has a $19.25 \%$ share. Given the magnitude of the problem, the first institutional responses began two decades ago - in 1997 with the adoption of a law regarding forced displacement (Law 387/1997).

However, today, many of the practical challenges remain just as before, such as whether it is possible to provide reparation to IDP s. ${ }^{70}$ Reparation measures are complex, take place over a prolonged period of time, and happen in parallel and often in an intertwined manner with other state interventions such as humanitarian assistance, development or the satisfaction of economic, social and cultural rights. As a result, the state has had to address the debate regarding the distinctions between these measures so as not to dilute the right to reparation of IDP s. Drawing distinctions between various measures is a challenging exercise. ${ }^{71}$ Even more complex is the implementation of these measures in practice. ${ }^{72}$ At the same time, given the reality of budgetary and institutional limitations, but also of opportunities to put in place better interventions, it is necessary to craft strategies so that each of these measures reinforces the others. Colombia offers important opportunities to put together a holistic link between these interventions given the content of the peace agreement between the government and the FARC.

Secondly, Law 1448 put the SNARIV in place with various branches and competencies to provide a range of interventions, from assistance to reparation. One positive aspect of this system has been the involvement of diverse actors in the policies related to victims. This broader involvement can lead to greater ownership of the measures and policy within state institutions. However, it also opens the door to the failures of these networks' own coordination. This aspect should be one of the main concerns of the reform process. Particularly, how to create better coordination with local authorities, and how to empower them while providing relevant technical capacity so that the system can become self-sustainable.

69 UNHCR, Global Trends Report, $2017,6$.

70 Report by the UN Special Rapporteur on the Rights of Internally Displaced Persons, 'International Displacement and Transitional Justice', UN Doc A/73/1 73, 17 July 2018.

71 Naomi Roht-Arriaza and Katharine Orlovsky, 'A Complementary Relationship:Reparations and Development' in Pablo de Greiff and Roger Duthie (eds), Transitional Justice and Development:Making Connections, (NY, ICTJ/Social Science Research Council 2009), 170213 and Peter Dixon, 'Reparations, Assistance and the Experience of Justice: Lessons from Colombia and the Democratic Republic of the Congo,' (2016) 10(1) IntlJ Transitional 88. Corte Constitucional, Colombia, C-1 19/2008, C-912/2013, C-o8o/2013. 
Finally, the question of when the IDP s' policy cycle can be closed still lingers. As of the date of the writing of this chapter, the Colombian Constitutional Court has continued to monitor the situation, to the extent that it still considers that an unconstitutional state of affairs remains in place. Certainly, as has been noted by experts on IDP s, addressing their injuries includes providing durable solutions that are part and parcel of reparation but also go beyond reparation as typically framed. Proposals for reform have to consider how effective the country has been in delivering durable solutions to IDP s, what has been the contribution of Law 1448 towards that purpose and how best to achieve that goal in the future. ${ }^{73}$

\section{E Conclusions}

Colombia has crafted a highly ambitious DRP under Law 1448 that is not comparable to any similar programme worldwide. It constitutes a holistic reflection of international law. However, the implementation gap is of huge proportions. After eight years of implementation approximately $10 \%$ of its target population have received compensation or rehabilitation. This reminds us that the challenge for the future is immense.

The year 2021 will mark the tenth anniversary of the Law and the end of its lifespan. This offers a unique opportunity to amend the Law and extend its life. To this end, relevant bodies of the SNARIV, and the Commission on Follow Up of Law 1448/2011, should make an evidence-based study to demonstrate the areas where the implementation of the Law has been successful and those where problems have been encountered. Bearing in mind the lessons learned, it is important that a national consensus takes place around the idea that no new forms of reparation would be added to the Law but rather to consider how best to articulate the existing ones in a way that empowers victims and maximises their impact.

Crucial for the future is how to ensure that not only the state bears the costs of reparations but also that other actors contribute to the process. In Colombia much more could be done to ensure that this is the case. It is one of the areas where the state has failed to make this happen, at its own expense.

Given the massive delays that have taken place so far, it is crucial to put in place some prioritisation criteria such as a territorial approach to victims, or to those victims who find themselves in an especially vulnerable situation so as to provide them with some forms of reparation as promptly as possible, bearing in mind the ability of those forms of reparation to have a positive impact in their lives such as rehabilitation for physical and mental health. 
It is also crucial to reconceptualise reparation so that some of its forms, like satisfaction, become more visible. Reparation can be better articulated to dignify victims and open opportunities for change in their communities and their lives. Key to this success would be the collaboration with civil society organisations. However, state institutions can also play a pivotal role in this regard by providing victims with an experience of the reparation system, as well as of transitional justice mechanisms that dignify them. Sometimes, it is not that much about how much to give a person or a community but how you treat them (the experience they have) that can make a lasting difference for victims.

Equally important is the work on collective reparation to help communities move forward. Well implemented collective reparations that have been developed on the basis of consultations with victims have the potential to help not only communities but also individual members of the community. Providing reparation to Afro-descendants and indigenous peoples is one of the biggest pending debts in Colombia. Collective reparation offers a meaningful form of redress for these groups.

While the ambitious spirit of the Law should be maintained, its execution needs to be planned with greater realism, and must duly entail a real effort on the part of the state to comply with it. To achieve this, Colombia requires a societal agreement on reparations for victims of the conflict, in which decisions are based on evidence and include the voices of different stakeholders, especially victims. Once an agreement is reached, the model should not be subjected to large-scale modifications (including the inclusion of new provisions or new categories of beneficiaries). New problems should be addressed by complementary arrangements or parallel interventions. This may give the entities in charge of the programme an opportunity to focus on actual implementation.

Finally, the Law could be very ambitious but Colombia, despite its armed conflict and all its consequences, is a country that is resilient by nature and capable to achieve what many believe to be simply impossible. Colombia has a pending debt. It has to show in the future that reparation for victims matters and that it is ready to do what it takes to achieve it.

\section{Acknowledgements}

Some of the data used in this article is the result of an Arts and Humanities Research Council (AHRC) funded project: Reparations, Responsibility and Victimhood in Transitional Societies, in which Professor Sandoval is a co-investigator. Professor Sandoval-Villalba is grateful to the AHRC for its support. 